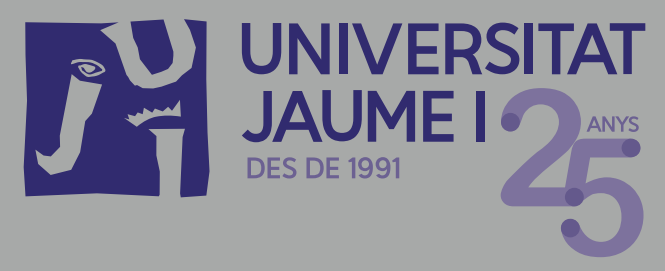

\title{
Relacions interpersonals i desenvolupament humà
}

Rosa Ana Clemente Estevan

\section{Lliçó inaugural del curs 2015/16}




\section{LLIÇÓ INAUGURAL DEL CURS 2015-2016}

\section{RELACIONS INTERPERSONALS I DESENVOLUPAMENT HUMÀ}

\section{Rosa Ana Clemente Estevan}

Catedràtica d'Universitat, Psicologia Evolutiva i de l'Educació Departament de Psicologia Evolutiva, Educativa, Social i Metodologia

Castelló de la Plana, 25 de setembre de 2015 
Edita: Servei de Comunicació i Publicacions Universitat Jaume I

Edifici rectorat i serveis centrals

Campus del Riu Sec

12071 Castelló de la Plana

www.uji.es·comunicacio@uji.es

Tel. 964728833

Dipòsit legal: CS-389-2015

http://dx.doi.org/10.6035/Llico.2015.2016

Imprimeix: Innovació Digital Castelló, s.l.u. 


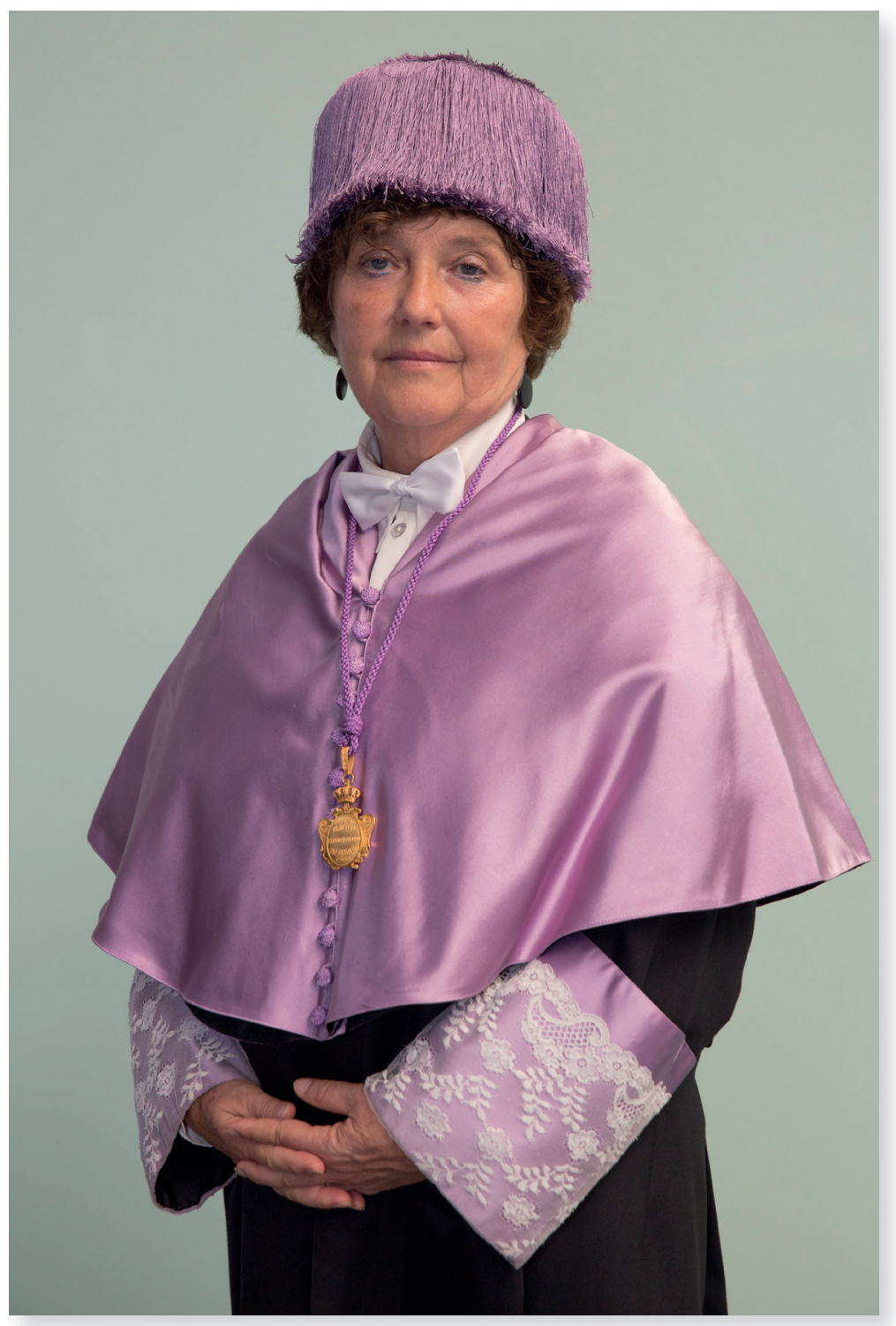




\section{ÍNDEX}

1. Un món complex sobre el qual actuar

2. Una teoria per a explicar

3. Un acompanyant o la responsabilitat del llenguatge

4. L'activació afectiva: les emocions

5. Un desajust: les interaccions hostils

6. Un trastorn associat: I'autisme

7. Una realitat: es manté i fins i tot millora en I'ancianitat 


\section{UN MÓN COMPLEX SOBRE EL QUAL ACTUAR}

En el món hi ha objectes i persones. L'ésser humà s'enfronta en el seu dia a dia amb aquests dos elements. La preocupació científica sobre el desenvolupament cognitiu socioemocional —el món de les persones- ha sigut molt tardana si es compara amb l'interès per la comprensió del món físic. No obstant això, la capacitat d'interactuar amb els nostres congèneres i que el cervell processe les conductes d'altres humans, constitueix un èxit excel.lent de l'espècie. Aquestes destreses són les que, per exemple, ens permeten comunicar-nos i aconseguir utilitzar eines tan competents com ara el llenguatge, la cooperació o la simulació.

Quan s'exerceixen accions sobre el món físic, sobre els objectes, se sol fer referència al desenvolupament cognitiu, ja que clarament la resolució de problemes materials ens enfronta, en cada edat, a dificultats que la ment intenta resoldre. Així, el bebè de pocs dies que xupla vigorosament un xupló i rebutja xuplar una manta -en només uns pocs assajos- és perquè la seua intel-ligència aprèn que, entre els objectes, n'hi ha de susceptibles de ser xuplats —el seu efecte és agradable, com ara el xupló- i no xuplables, ja que tornen un efecte desagradable, com ocorre amb una manta d'abric. Durant tot el desenvolupament, es tinga l'edat que es tinga, ens enfrontem amb una gran quantitat d'objectes que aconseguim controlar, dominar, utilitzar... o no. Els objectes no han de ser necessàriament materials i presencials, com el xupló o la manta en el bebè, a partir dels divuit mesos -i de forma cada vegada més complexa- solen ser ja represencials (representats), per tant, ser paraules, fórmules, signes, o notes musicals.

Amb tot, d'això va aquesta lliçó, entre tot allò que ens envolta també hi ha persones. No sols mantenim relacions afectives amb elles, també ens 
proporcionen suport perquè ens enfrontem amb més èxit amb el món dels objectes i són, en si mateixes, objecte de coneixement en allò que coneixem com a «cognició social». Saber el que els altres pensen, senten, creuen o pretenen té, des del punt de vista del que aporta la naturalesa, una funció adaptativa, ja que es produeixen guanys en poder colllaborar en grup i regular les accions pròpies en funció del que s'espera dels altres i del que els altres esperen de nosaltres.

El nadó ja ha passat un bon nombre de mesos en el si matern, per tant, arriba al món amb un important bagatge de conductes. No obstant això, com és ben conegut, necessitarà durant molt de temps el suport dels seus majors, adults/es lligats a ell per l'emoció de l'amor d'afecció, un dels lligams més forts que, com a animals, els éssers humans compartim amb altres espècies. D'aquesta manera comença la criança i la comprensió per part de la ment infantil del fet que entre el que l'envolta hi ha éssers animats amb directrius d'acció pròpia.

Els investigadors han arribat fins i tot a postular regles sobre com els bebès aprenen a diferenciar els objectes de les persones. Així, per exemple, abans de comprendre el que es coneix com a «intenció», cosa que ocorre de forma incipient als voltants del setè i vuitè mes de vida, els xiquets i xiquetes han de reconèixer que els éssers humans, a diferència dels objectes, són: recíprocs (els humans reaccionen entre si), contingents (la seua reacció està relacionada amb la dels altres), i comunicatius (es transmeten informació) i, prèviament, que els objectes es comporten per la reacció d'un altre objecte o persona, mentre que les persones tenen la seua pròpia subjectivitat $\mathrm{i}$ poden actuar pel seu compte.

Les persones són objectes desitjats des del principi i específicament interessants. El bebè pareix acontentar-se amb les persones com si foren el més atractiu del món. Els adults encarregats de la criança i els xiquets i xiquetes practiquen un intercanvi recíproc, es contemplen mútuament i emeten sons segons els canvis de veu i observen mútuament el seu aspecte. Cuidador/a i bebè no sols es troben al món, sinó que hi són junts. Açò és clarament un assumpte d'amor, de moment, molt resilient, sense les conseqüències dramàtiques que té uns mesos després. El cuidador o la cuidadora comença a emprar ací una forma de parlar (maternès) que aconsegueix en només dos anys introduir els xiquets i xiquetes en els amagatalls de la llengua (o llengües) del seu medi. Sabem per les investigacions amb aprenents incipients de les llengües naturals, que en aquest nivell, els xiquets 
i xiquetes estan «oberts a les llengües del món», de manera que només la interacció interpersonal amb adults experts els transforma en parlants de la seua llengua o llengües maternes (anglès o xinès, monolingües o bilingües). D'altra banda, a poc a poc, entra en joc la memòria de treball, que va fixant:

a) d'una part, les rutines de tipus interactiu: «si xarrotege, em somriuen, es queden i m'imiten...» reforçades i repetides, van construint la memòria infantil, de manera que finalment el bebè anticipa que quelcom succeirà després d'un xarroteig;

b) d'una altra, l'aprenentatge dels continguts repetits: la / $\mathrm{r} /$ forta casteIlana o la /z/ sonora del català, i així amb tots els fonemes estadísticament més emprats pels seus parlants, de manera que gradualment el cervell infantil manté i s'ajusta a les característiques lingüístiques del que serà la seua llengua o llengües maternes.

Cap als cinc mesos, amb l'ús de les mans, el món físic guanya el món social, però els adults i adultes socialitzadors descobreixen als menors que es poden combinar l'interès per les coses, amb el desig d'estar amb les persones i apareix l'atenció compartida i les interaccions a tres bandes (adult, xiquet i objecte). Aquest nombre màgic, el tres, serà útil per sempre i, sens dubte, la millor forma de donar suport a l'aprenent en la seua vida preescolar.

Com cada dia es comprova, els bebès són molt més capaços del que intuïtivament es pensa; els adults tendim a buscar conductes semblants a les nostres per a jutjar les seues competències mentals $i$, en aquest sentit, els bebès no demostren habilitats, ja que no parlen, no caminen o ho fan amb dificultat, són maldestres amb les mans, etc. Els treballs més recents demostren que quan es troben variables de mesurament adequades es pot comprovar com la seua conducta deixa de ser incompetent. Així, per exemple, pel sistema tècnic d'avaluar el seguiment dels seus ulls demostrant atenció, sabem que associen prompte objectes amb paraules, o que tenen «permanència d'objecte» abans que conductualment puguen alçar una pantalla i demostrar fefaentment que un objecte no desapareix a pesar que estiga ocult darrere d'una coberta. I el mateix ocorre amb un bon nombre de conductes lligades a la intencionalitat, al llenguatge, al reconeixement emocional, a la imitació, etc., que els investigadors dissenyen per a trobar el mode d'avaluar-les sense haver de recórrer a l'explicació lingüística o a l'acció directa sobre els objectes. 
La imitació dels altres és una de les eines interpersonals més poderoses que els xiquets i xiquetes tenen per a comportar-se com a humans. Encara es discuteix la seua precocitat, però com en tot, pareix més primerenca del que observacionalment es percep. Els nostres bebès, els bebès dels humans, són molt competents en la imitació i aquesta capacitat serà sempre una conducta rellevant per a les noves adquisicions, especialment de les rutines socials. Els detractors de la imitació ho són perquè la solen oposar a la brillantor de les conductes espontànies i originals, i ningú posaria objeccions a aquesta comparació; no obstant això, per a ser original es necessiten moltes adquisicions prèvies que la imitació ajuda a construir. A més, la imitació manté un elevat nivell d'esforç personal, ja que la conducta imitada, a més de ser recognoscible per a complir els fins del model, manté un intercanvi intermodal, ja que el que veiem o sentim ha de ser reproduït canviant la modalitat executiva, és a dir, exercitant actes motrius amb el cos o amb les cordes vocals i l'aire de la respiració.

Els bebès humans, a diferència dels dels ximpanzès, imiten accions sense cap fi, aparentment aberrants i inútils a efectes pràctics (sobreimiten) i això és el que probablement els indueix a arribar més enllà, a anar més lluny en l'escala evolutiva. No és aberrant beure d'una tassa buida? o donar a menjar a una nina, incapaç de menjar, amb una cullera sense menjar?, però això és simulació i dirigirà la ment infantil cap a nous nivells de cognició més elaborada. Nivells cognitius en què manegen realitats substitutes, representades per signes, símbols o notes musicals que no tenen més realitat que la d'allò que tècnicament substitueixen, però que aconseguiran progressos molt més potents al llarg del desenvolupament.

En aquestes pàgines introductòries s'ha realitzat una oposició entre el coneixement d'objectes i persones, però, ¿què ocorre i ocorrerà amb la gran quantitat d'artefactes tècnics que, cada dia més, realitzen accions semblants a les humanes? La tecnologia fa açò possible i ho continuarà fent molt més en els futurs anys. Què passa, per exemple, amb els robots? Els xiquets $\mathrm{i}$ xiquetes, es comportaran amb ells com si foren humans o com si foren objectes? Alguns artefactes no tenen forma humana, per la qual cosa la imitació no sol funcionar, i les criatures els tracten com a objectes, sense implicacions emocionals. Ara bé, què ocorre si es tenen les característiques morfològiques semblants a les d'un humà? Respecte d'això, ja s'han fet algunes investigacions $i$ es comprova que els bebès $i$ els menors reaccionen de forma diferent davant les accions mecàniques que davant les humanes 
en estricta correlació amb la semblança que tinguen les conductes entre ambdós actors. Estudis recents estan suggerint que a l'infància s'està més interessat a imitar les accions humanes que les mecàniques; especialment, els menors de dos anys es resisteixen a imitar accions fetes per dispositius no humans, així com accions realitzades per mans amb manyoples o pinces mecàniques. La variable clarament rellevant és la capacitat que tinga la tecnologia d'enginyar androides que, realment, copien els senyals interactius nuclears dels humans. En aquest sentit, un estudi publicat recentment va trobar que els xiquets i les xiquetes de dos a tres anys eren més capaços d'ajudar un robot que tenia dificultats a ficar grans en una tassa quan, abans i després de l'acció errònia, mirava als ulls al xiquet/xiqueta participant. L'explicació podria estar en la capacitat infantil d'interpretar les intencions de les accions, en aquest cas, del valor cooperatiu de contacte ocular, típic dels éssers humans per a demanar ajuda, mentre que les accions realitzades per robots o artefactes mecànics (directes, sense atenció al mentalista) podria no induir a simular-les mentalment $\mathrm{i}$ imitar-les o entendre-les.

D'altra banda, no hi ha cap dubte que la tecnologia ens acompanya i continuarà influint en les nostres actituds i conductes. Especialment, estan sent d'interès en entorns de suport als aprenentatges escolars. També són cada vegada més freqüents les plataformes robòtiques que tenen interès interactiu, que són companyes de jocs o que incideixen en entorns de rehabilitació psicològica infantil i adulta.

\section{UNA TEORIA PER A EXPLICAR}

En el marc de les relacions interpersonals s'adquireix la capacitat mental de pensar sobre el que pensen els altres. S'ha denominat Teoria de la Ment (TM) a aquesta capacitat, fent referència al fet que es tracta realment d'un sistema d'inferències (teoria) que formulem mentalment per a fer prediccions de la conducta dels altres. Per tant, fa referència l'acrònim a la capacitat dels éssers humans per a, en algun moment del seu desenvolupament, ser capaços d'atribuir als altres i a un mateix, estats mentals i, basant-se en aquests, tenir la competència suficient per a explicar i predir la conducta aliena. D'aquesta manera, interpretem estats emocionals, intencions, desitjos 
i creences dels altres. Encara que el xiquet o xiqueta porta un llarg període previ de comprensió de realitats preteses, no serà fins al final dels tres anys quan s'observen indicis excel-lents de compressió del món dels estats mentals aliens. Entre els quatre i cinc anys els xiquets i xiquetes superen amb èxit les proves estàndard de TM — la més rellevant és la denominada de la falsa creença, consistent en la predicció de l'acció d'un personatge basat en la seua creença errònia, inhibint la resposta real— i són capaços de donar raons verbals, mitjançant les quals descriuen les atribucions que fan sobre els altres. Aquesta sofisticada activitat del pensament es manté durant tota la nostra vida i té precursors precoços (com les ja mencionades atribució d'intencionalitat, atenció compartida i mirades conjuntes), continua la seua evolució fins als nou o deu anys, edats en què s'és capaç de comprendre aspectes mentalistes més complexos relacionats a) amb el llenguatge, com ara les ironies, les ficades de pota o els dilemes morals, $\mathrm{i}$ b) o amb la comprensió d'emocions secundàries simultànies i de valència oposada, o la distinció d'aparença i realitat emocional.

Pel que fa als estats mentals, desitjos i creences constitueixen la base de l'acció humana. Ambdós són emprats per a explicar les nostres accions. Respecte al desig, és sens dubte de naturalesa personal i interpersonal: desitgem èxit, riqueses, possessions, etc., per a nosaltres i per als altres. Desitgem als altres «bona sort» o «el millor» o «feliç any nou», fórmules de cortesia o frases fetes d'adults que s'han mimetitzat per a facilitar la convivència i la interacció. Els desitjos pareixen indicar «la falta de quelcom» i sentim emocions positives quan els assolim i negatives quan no podem aconseguir-los. No obstant això, els desitjos també impliquen quelcom global Iligat a altres processos mentals de manera que, per exemple: desitgem menjar com a resposta a una necessitat bàsica, però no qualsevol cosa i no si estem a dieta, etc. En nombroses ocasions, i açò constitueix una ocupació: la de publicista, és necessari pensar en la globalitat mental — de la ment dels altres- que subjau en el desig si es volen crear «noves necessitats» en els futurs consumidors. Des del punt de vista evolutiu, els xiquets i xiquetes de tres anys comprenen que els altres tenen desitjos i que aquests desitjos puguen tenir un cert grau de conflictivitat amb els desitjos propis. I és més, criatures de divuit mesos, però no els de catorze mesos, donaven a un experimentador bròquil en compte de galetes, quan aquest els deia, mitjançant gestos i llenguatge, que tenia fam; prèviament, l'experimentador 
els havia convençut (també recolzant-se en gestos) que ell preferia el bròquil a les galetes.

Respecte a les creences, són també entitats del pensament, però es tracta de cognició insegura, ja que són «interpretacions» personals o grupals, però no tenen per què estar veraçment relacionades amb els successos. No obstant això, són molt rellevants perquè dirigeixen la conducta humana, ens fan actuar, ens mobilitzen. Des del punt de vista que es descriu ací, és per a considerar la seua universalitat i precocitat. Els preescolars ja són capaços de comprendre que el que es creu en moltes situacions pot ser fals. Així, entenen que Caputxeta puga creure que el llop disfressat siga la seua iaia, atès que aquesta creença no està basada a compartir la realitat (la disfressa que porta el llop i que fa que Caputxeta —innocent respecte a aquest fet - tinga una falsa creença); no obstant això, les criatures a les quals els contem el conte han sigut observadors del canvi i al mateix temps que comprenen la falsa creença de Caputxeta saben de la realitat, de qui està realment al llit. És per açò que una creença no és coneixement cert, és una suposició dirigida pels successos que no controlem totalment, però els humans fem aquestes suposicions contínuament, és més, no podem deixar de fer-les, a partir dels quatre o cinc anys i pensar que podrien no ser del tot concordants amb la realitat.

Encara un enllaç més: d'aquestes creences, com dels desitjos, es deriven emocions. En el cas de l'exemple anterior, Caputxeta no ha de tindre por, ja que creu que qui està al llit és la seua iaia; en tot cas, hauria de sentir tristesa, ja que està malalta. Molts menors de cinc anys responen "por» a la pregunta "Què sent Caputxeta?», fins i tot encara que hagen comprès que Caputxeta creu que qui està al llit és la seua iaia. El que es produeix és una interferència davant de la pregunta per l'estat emocional que fa aflorar la comprensió personal de la veracitat del succés, del qual els xiquets i xiquetes entrevistats són sabedors. L'emoció ennuvola la creença?

Actualment se separa entre TM de caràcter cognitiu fonamentada a teoritzar sobre les creences i els estats mentals i TM afectiva, la que utilitza els mateixos paràmetres per a explicar conductes lligades a l'àmbit emocional. Les localitzacions cerebrals utilitzant tècniques d'imatge per ressonància magnètica (fMRI) estan registrant una xarxa de regions que es coactiven quan s'interroga els participants sobre estats mentals propis o dels altres, que inclou el solc posterior superior del temporal i la unió temporoparietal i el còrtex prefrontal medial. Quan es pregunta sobre emocions en la 
TM afectiva s'activa, a més, la zona ventromedial del còrtex prefrontal. Açò passa més en adolescents que en adults, la qual cosa demostra que encara es produeixen canvis evolutius en aquests conceptes i a edats avançades.

\section{UN ACOMPANYANT O LA RESPONSABILITAT DEL LLENGUATGE}

Un dels focus d'interès en els quals el meu grup ha investigat aquests conceptes ha sigut establir la relació entre la comprensió de la ment dels altres i el llenguatge. Molts altres grups treballen sobre el mateix tòpic, la raó rau bàsicament en el fet que ambdues conductes són contemporànies i solen fracassar una amb l'altra en el desenvolupament atípic. En principi, la relació és fàcil de contemplar en reconèixer que en la interacció sociocognitiva està implicada la comunicació, per la qual cosa els orígens comunicatius del llenguatge coincideixen amb la possibilitat que els altres ens facen partícips del que estan desitjant, sentint o creient. La comunicació lingüística es beneficia del contacte ocular, de la intencionalitat pragmàtica, de les tasques compartides i de l'atenció conjunta. Comunicar és expressar els nostres pensaments, desitjos, intencions, emocions als altres i comprendre els dels altres. Per tant, el dialogue interpersonal seria el tipus discursiu més enjorn pel que expressem la nostra ment i comprenem la dels altres. Ser capaç de processar les característiques discursives del diàleg significa poder respectar torns, ser contingent amb les propostes alienes, ser sensible al que altres expressen, etc. I això és interpersonal. Mitjançant aquesta comunicació els xiquets i xiquetes a més d'aprendre les llengües naturals, se socialitzen, adquireixen la teoria de la ment dels altres, es fan persones que viuen en un món de persones.

Alguns dels components de la llengua s'han investigat per a establir relacions, així com conèixer què antecedeix a què. La morfosintaxi va tenir el seu temps de revelació en la mesura en què les oracions de complement (amb verbs com ara «pensar» o «dir») representen la paradoxa de valorar la realitat dels successos i el món mental dels agents actius. Aquests enunciats poden ser falsos realment, sent verdadera l'oració implicada. Per exemple, 
en la frase: «Maria pensava que Lluïsa li havia llevat els caramels», no se sap si el que es diu està relacionat amb la realitat, però en la seua globalitat sabem que només és assumible en la mesura que creguem que es tracta d'una creença de Maria.

La semàntica va tenir la seua època daurada i el meu grup ha contribuït a publicar sobre això, establint, en situacions de diàleg entre adults i criatures mirant contes conjuntament, la capacitat dels adults per a usar explicacions mentalistes de les històries narrades o explicitades en les il.lustracions. Respecte d'això, hem comptabilitzat el tipus de lèxic, el temps dedicat als tòpics mentalistes, el nivell de justificació, etc. Els resultats van assenyalar correlacions i un alt nivell de predicció entre aquestes variables i la capacitat de superar tasques de laboratori de caràcter mentalista. De la mateixa manera, encara que serà motiu de reflexió posterior, hi ha relació entre el llenguatge mentalista dels adults de criança en situacions d'interacció informal i la comprensió emocional de les criatures a càrrec seu.

Un tercer component del llenguatge està ara capitalitzant el nostre treball, és la pragmàtica. Fàcilment s'observa que parlar es fa per alguna raó i que això té molt a veure amb els altres que comparteixen la llengua. I encara més, la pragmàtica organitza la ment per a poder representar estats mentals sense necessitat d'exercir-los empíricament. Les llengües naturals estan farcides de figures literàries que manipulen un sentit figurat superposat al sentit real, així com enunciats que es diuen amb una intenció diferent de la que la frase pareix manifestar de forma superficial. Els bons parlants amb bona capacitat interactiva i mentalista no solen tenir problemes a manejar-se adequadament davant d'aquestes «irregularitats». Al llarg del desenvolupament els menors les escolten i van generant la comprensió encertada. Algunes de les proves amb què hem treballat tenen a veure amb la comprensió d'ironies, frases fetes, acudits, ficades de pota, etc., en totes es pregunta als participants (generalment davant de vinyetes dibuixades) sobre el que es diu, per què es diu i quina és la intenció de l'emissor. En aquest cas hem utilitzat participants amb dificultats interactives i pragmàtiques, és a dir, xiquets i xiquetes afectats d'autisme o de trastorn de la comunicació social, els resultats que es comentaran més endavant estableixen diferències significatives, especialment en les raons per les quals fan atribucions d'intencionalitat. 


\section{L'ACTIVACIÓ AFECTIVA: LES EMOCIONS}

Una altra de les conductes que s'inclouen en les competències socioemocionals fruit de la interacció a adquirir al llarg del desenvolupament són les emocions, amb totes les seues capacitats: expressar, reconèixer, comprendre i regular; i amb totes les seues complexitats: emocions positives i negatives, primàries i secundàries, aïllades i complexes, ocultes i demostrades, contradictòries, etc.

Actualment, l'àrea emocional gaudeix de molt bona salut dins de la psicologia del desenvolupament. Gran part d'aquesta afirmació es deu a la reconversió de la tradicional relació amb la cognició en àrees populars amb implicacions terapèutiques i d'intervenció (empatia i intel-ligència emocional), però també a desenvolupaments propis lligats a la competència social i a la regulació.

La comprensió emocional, que es desenvolupa en les primeres etapes del canvi evolutiu requereix, a més de les vivències reals, de l'explicació interactiva donada als xiquets i xiquetes dels distints successos i accions que provoquen els diversos estats emocionals. Aquesta via d'explicació és real (quan incidentalment es produeix un esdeveniment que ho requereix) però sovint és justificada i ampliada pels cuidadors per a tenir ocasió de reforçar les adquisicions que van a poc a poc implementant en les seues criatures. Per aquesta raó, un corrent bastant rellevant en Psicologia del Desenvolupament, dins del qual es troba el meu grup, entén que aquest procés té alguna cosa a veure amb els comportaments lingüístics que els adults de criança desenvolupen quan interactuen amb els seus fills i filles. Ells, van introduint en les vides dels seus fills les implicacions socioemocionals que consideren rellevants per al desenvolupament social de les seues criatures. Les conversacions entre pares i fills sobre successos que desencadenen respostes emocionals solen estar centrades en emocions negatives (por, enuig, tristesa, vergonya o culpa), hem comprovat que per a aquestes emocions les argumentacions són més freqüents i explícites, es realitzen més preguntes obertes i tancades, es fa més referència a successos passats i es relacionen amb més freqüència les emocions amb altres estats mentals. L'explicació més encertada pareix estar en el desig parental de regular la intervenció infantil en els successos que provoquen aquestes emocions, així com evitar el possible patiment. L'emocionalitat positiva (menys conversada però 
igualment activa) apareix centrada en l'amor de vinculació i en les situacions de felicitat assolides per a obtenir desitjos, protecció, contacte i afecte. Un altre focus d'atenció simulat per a aconseguir millores en la competència emocional el proporcionen els contes; compartir una història o un conte conjuntament amb un adult d'afecció és un dels sistemes mitjançant el qual els adults ensenyen als seus fills nombroses rutines cultuals i socials, entre les quals es troben la comprensió i la regulació emocional.

Entre els tres i els sis anys, la por i la còlera comencen a ser estables i a ser menys freqüents. No obstant això, es refermen les emocions de tipus secundari o moral, com ara la vergonya o la culpa, en gran part degudes al gran nombre d'experiències distintes que s'obrin al seu voltant en generalitzar-se els seus contactes amb els agents escolars. L'escola i els iguals, a diferència de la família, obliguen a rendir segons les pròpies competències, a exercir la individualitat i a tenir nombroses ocasions autònomes de controlar els sentiments personals. A partir d'ací, la millora de coneixement i el control augmenten progressivament amb l'edat, encara que la progressió és lenta $i$ arriba fins als adolescents.

Finalment, la interacció amb iguals fa florir amb intensitat les relacions afectives i emocionals Iligades a l'amor d'iguals en totes les seues formes: camaraderia, amistat i, més tard, enamoraments lligats als desitjos de plaer sexual i d'intimitat. L'afecte interpersonal genera, probablement, les situacions interactives més positives que podem mantenir al llarg del cicle vital.

\section{UN DESAJUST: LES INTERACCIONS HOSTILS}

D'altra banda, la capacitat d'atribuir estats mentals és probablement una eina socialment neutral que es pot aplicar als dos pols interactius: la prosocialitat amb conductes com ara ajudar, consolar, informar, i les conductes amb objectius antisocials, com poden ser enganyar, manipular o excloure.

Algunes de les tasques de Teoria de la Ment són negatives moralment, com ara la capacitat d'enganyar i mentir. Mentir és dir o manifestar el contrari (o una distorsió) del que se sap, es creu o es pensa. Enganyar és donar a la mentida aparença de veritat. També poden haver-hi mentides piadoses o 
mentides que afavoreixen la convivència, molt abundants entre aquells que mantenen relacions afectives. Aquest és el cas quan valorem com molt bo un dibuix del nostre fill de tres anys o diem que ens encanta un regal. Els objectius poden ser diferents, però en general es produeixen per a evitar malestar dels que estan en el nostre entorn.

Enganyar requereix la voluntat de manipular la conducta de l'altre amb l'objectiu de generar en l'altra persona una creença falsa. Es requereix pensar en la ment de l'innocent i dirigir els estàndards de la conducta pròpia per a manipular la creença falsa en la ment ingènua. Un exemple característic és quan es tira la culpa a un altre i qui ho fa configura el que fa i el que diu per a fer creure als altres quelcom diferent d'allò que ha succeït, ocultant voluntàriament el succés real. Ara bé, fora de repercussions morals, enganyar -i enganyar amb èxit- és una conducta cognitivament elevada altament relacionada amb els mesuraments d'intel.ligència, ja que requereix no sols les capacitats verbals per a exterioritzar l'esdeveniment, sinó també capacitats executives per a planificar-lo i organitzar-lo, com ara la memòria de treball, o el control inhibitori. Altres formes elaborades d'enganyar són característiques del desenvolupament adolescent i adult, com per exemple: la hipocresia, l'exageració, les calúmnies, el fingiment, la falsificació, les excuses, les estafes, les trampes, les dissimulacions, etc.

Avançant en el desenvolupament humà, es descobreixen que algunes de les eines que s'utilitzen en la interacció amb iguals tenen relació amb la comprensió d'aquestes nocions. L'atribució d'intencions hostils, a vegades a simples accidents, és típicament evidenciada durant els anys escolars. La investigació ha demostrat que tant les agressions com la conducta prosocial es relacionen amb els aconseguiments en cognició social. Així, escolars amb bones capacitats per a comprendre les emocions i intencions dels altres són percebuts pels seus iguals com més assequibles i amb menors conductes disruptives, tot just al contrari respecte als que exerceixen conductes indesitjables o maldestres socialment.

Les relacions socials saludables requereixen una adequada comprensió mentalista, per la qual cosa els xiquets i xiquetes amb dificultats en la comprensió de les tasques de TM tenen dificultats a establir bones relacions entre els seus iguals en èpoques escolars $i$ adolescents. Els xiquets i xiquetes rebutjats, en concret, són poc eficients a l'hora d'interpretar les intencions 
socials dels seus companys i iguals. Alguns estudis han detectat que tenien més facilitat per a detectar les intencions negatives que les positives. El nostre grup ha investigat aquest supòsit comparant la comprensió de diverses tasques mentalistes relacionades amb l'engany. Un dels resultats obtinguts mereix especial consideració: en una tasca de la mentida piadosa, els participants rebutjats, a més de ser menys capaços de reconèixer el valor mentalista de la prova, quan donaven explicacions ho feien referint trets hostils, és a dir, fent atribucions intencionals negatives al succés que presentava la tasca. Una possible explicació seria pensar que els xiquets i xiquetes rebutjats han viscut successos al llarg de la seua escolaritat on han rebut impressions d'interaccions negatives per part dels seus companys o companyes, per la qual cosa actuen esbiaixant negativament les intencions dels altres.

Durant les èpoques escolars de la secundària, és a dir durant la preadolescència, és el moment en què s'aglutinen tant les interaccions positives com les relacions indesitjables i hostils amb els iguals. La preadolescència és una època difícil en les cultures occidentals, és època de canvis físics amb modificacions tan dramàtiques com les dels bebès. Així, durant la pubertat, el cervell deixa d'afegir automàticament noves connexions i es torna més eficient recablejant les conduccions nervioses, la qual cosa les agilitza i s'obtenen beneficis en l'aprenentatge, però al mateix temps (i per això s'ha comparat els púbers amb un vehicle sense frens) es produeixen desfasaments entre les connexions cerebrals, de manera que el sistema límbic emocional està madur abans que els centres de control del frontal assolisquen l'organització adulta. Aquest desfasament dóna com a resultat que els adolescents siguen capaços d'entendre els riscos i conseqüències de moltes de les seues conductes, però valoren més l'activació relacionada amb el plaer, la cerca de sensacions i les recompenses immediates que es puguen derivar de les seues accions, especialment les generades pels seus iguals. Els pares van minorant la seua influència al mateix temps que els iguals la consoliden de forma molt rellevant.

Les relacions en què els iguals estan implicats són, en aquesta etapa del desenvolupament, molt fructíferes positivament i negativament, florint tant les emocions positives Iligades a l'amistat, la camaraderia o l'enamorament, com les negatives Iligades a l'assetjament. Com és conegut, s'usa el terme bullying per a les experiències d'assetjament físic i psicològic continuat exercit pels iguals. Els menors amb baix nivell en TM tenen més risc d'estar 
implicats en episodis d'assetjament, victimització i maltractament perquè són maldestres en la utilització de les eines mentalistes útils en el dia a dia de la interacció. A més, tenen menys habilitats per a detectar els senyals que determinen les intencions o emocions dels altres, així com poques habilitats per a eixir airosos dels conflictes, amb la qual cosa es dificulten les relacions recíproques. Finalment, com s'ha comentat, per la interpretació equivoca de les situacions i veure-hi intencions hostils en situacions ambigües. Aquesta malaptesa interactiva els fa ser vistos com a "companys estranys», la qual cosa incrementa el rebuig i fa augmentar el risc de ser victimitzat. No obstant això, qualsevol pot ser víctima, ja que altres variables lligades a la personalitat, a l'aspecte físic i a l'autocontrol també aporten la seua influència. Així, els escolars amb poc control davant de les emocions negatives són incapaços de no deixar-se portar per la tensió del moment i no inhibir conductes d'hostilitat cap als seus iguals. Segons pareix, la comprensió de la ment dels altres és necessària però no totalment suficient per a explicar la competència social, és a dir, la conducta real i manifesta.

\section{UN TRASTORN ASSOCIAT: L'AUTISME}

Ara bé, no sols s'estudia la conducta sociocognitiva de desenvolupament típic, sinó també les variacions en el desenvolupament que porten a tenir dificultats en aquest tipus de comportaments. El trastorn més rellevant dels estudiats als quals els afecta la cognició social és l'autisme.

L'autisme, segons les últimes referències, afecta un de cada cent individus; es tracta d'un trastorn crònic, sembla que congènit i altament heretable. Les seues manifestacions són molt variades, ja que constitueix un espectre de molt àmplies competències i conductes. És un trastorn del neurodesenvolupament que se sol detectar a partir dels dos anys, quan els observadors naturals dels xiquets i xiquetes s'adonen de la seua falta d'atenció compartida. Les dificultats es presenten en la comunicació i la interacció interpersonal, la presència de patrons repetitius i estereotipats de conducta, els interessos restringits i l'escassa flexibilitat mental. Dins de la gran variabilitat fenotípica 
del trastorn influeix el fet que pot presentar-se amb dificultats intel.lectuals o de llenguatge o sense.

El treball d'investigació sobre aquest trastorn, en els últims trenta anys, ha modificat els coneixements que es tenien sobre la psicologia dels xiquets i xiquetes típics, especialment la dels preescolars; gràcies a l'estudi de les seues dificultats, es van descriure els mecanismes involucrats en la inferència d'estats mentals, així ha ocorregut amb el mecanisme d'atenció compartida, amb la comprensió de la intencionalitat o amb la capacitat de detectar evolutivament els artefactes mentalistes de les llengües naturals. I el camí de tornada ha propiciat el reexamen d'aquestes capacitats danyades a la llum de la conducta típica, reavaluada sota les noves perspectives. L'autisme ens ha ensenyat a valorar la cognició socioemocional, a centrar els objectius evolutius i educatius en àrees abans no reconegudes a pesar de la seua visibilitat $\mathrm{i}$ evidència.

En el desenvolupament típic, com s'ha vist, els processos d'interacció social són molt primerencs: preferir veus humanes, rostres i carícies, està present des de les primeres hores i setmanes de vida. Aquests processos estableixen les bases per a l'especialització social i interactiva de la ment i se sap que aquestes capacitats són informades pels pares com a no presents o immadures al voltant del segon aniversari dels seus fills i filles. A aquestes edats els pares comencen a ser conscients de regressions $i$ alteracions qualitatives en el desenvolupament, evidenciades per un perceptible aïllament, limitació o absència del llenguatge, sordera paradoxal, presència de rituals $\mathrm{i}$ absència de competències interactives i de ficció. En els últims anys s'estan realitzant grans esforços per al diagnòstic primerenc a fi d'avançar la intervenció a èpoques en què el cervell encara pateix canvis molt rellevants. La revista Nature va publicar el 2013 un article en què s'examinaven de forma retrospectiva i longitudinal, amb proves d'atenció a rostres humans (el de la mare), nadons d'alt risc d'autisme (aquells que ja tenien un germà major diagnosticat), i es va comprovar -en aquells participants el diagnòstic dels quals va ser finalment d'autisme- que l'atenció dirigida cap als ulls d'una altra persona no es perd totalment, però descendeix ja a l'edat de sis mesos. De nou, es comprova que amb tècniques adequades es poden establir més prompte la direccionalitat de les dificultats $i$ instaurar diagnòstics primerencs 
que beneficien extraordinàriament la capacitat d'iniciar el tractament en edats cada vegada més precoces.

En els xiquets i xiquetes autistes la seqüència evolutiva en els èxits interactius és atípica, habitualment necessiten més edat que els seus controls per a resoldre les tasques d'interacció i de TM, i solen usar camins no habituals per a enfrontar-se amb aquests problemes, tant en la vida real com en el laboratori. En general, són poc capaços de triomfar amb eines intuïtives en què la infància típica reïxen de forma molt capaç. Per exemple, comprenen literalment enunciats figurats com ara: «estar fet pols» o «estar en pilotes», locucions en què la simple interacció fa que els seus controls d'edat comprenguen sense grans esforços. En línies generals, són poc hàbils en les converses $\mathrm{i}$ incompetents per a ajustar les seues intervencions al nivell de coneixement de l'interlocutor, així com als seus desitjos, interessos i emocions i, per descomptat, processen malament les indirectes, ironies i inferències verbals.

El nostre equip ha mesurat xiquets i xiquetes amb diagnòstic d'autisme, entre altres, amb bon nivell mental. Hem utilitzat tasques variades i alguns exemples permetran valorar-ne les dificultats. Per exemple, quan s'utilitza una tasca de mentida piadosa (hem utilitzat diverses vegades les vinyetes del regal no desitjat, en què algú que desitjava uns patins, rep en el seu aniversari una pilota), en les seues respostes solen indicar la realitat de la situació, i expliciten que la cara de content o les verbalitzacions com que els agrada són per motius aliens al procés central, a causa per exemple, que estan en una festa o amb amics o que també els agrada l'altre regal. En diverses ocasions hem utilitzat tasques de naturalesa moral, com la de la xiqueta que fa cua per a aconseguir un gelat i no respecta el torn, l'explicació dels autistes és veure la realitat amb bones intencions i dir «s'ha colat perquè li agrada el gelat de llima (era el tipus de gelat dibuixat)». En general, comprenen la moralitat de la situació i reconeixen que l'acció no s'ha de fer, però la seua explicació de la intencionalitat es deriva cap a arguments positius, encara que clarament el fet relatat té naturalesa negativa. En això són diferents dels participants típics rebutjats. La comprensió literal és el més habitual i aquesta és la raó per la qual es retarden a comprendre i utilitzar aquest tipus de recursos, encara que es beneficien de la intervenció, mai arriben a ser destres en el maneig d'aquests recursos de la llengua. 
És habitual usar l'argument que l'autisme es construeix a si mateix, en el sentit que el cervell infantil va especialitzant-se en allò sobre el que estadísticament presta més atenció, de manera que si no hi ha una clara distinció entre el món de les persones i el de les coses i aquestes últimes acaben resultant més atraients, cada vegada s'allunyen més de les experiències compartides, que com s'ha repetit, propicien l'aprenentatge social. El seu cervell necessita ser estimulat en el sentit triat per la nostra espècie: el social, per la qual cosa es fa necessari intervenir com més prompte millor educativament (en els centres i la intervenció) i socialment (en les famílies, els grups de companys, etcètera).

Mai es remarcarà prou en quina mesura les experiències en contextos reals són necessàries. La intervenció adequada en situacions donades pareix un element molt rellevant per a eixir airós en situacions d'engany. Així, hem trobat que els xiquets i xiquetes de desenvolupament típic actuen de forma molt competent després de ser alliçonats i practicar amb els regals de la seua primera comunió. Ídem, d'haver sigut amonestats després de no assumir les conseqüències dels seus actes, en les situacions d'emocions de culpabilitat. Calia esperar que el mateix ocorreria amb els xiquets i xiquetes afectats d'autisme, no obstant això, les ocasions de tenir aquest tipus «de relliscada interactiva» descendeixen en generar i desenvolupar moltes menys situacions d'interacció. Aquest és un punt clau per a reivindicar centres d'interacció amb iguals (escoles i altres instàncies d'intercanvi social) normalitzats on les ocasions d'intercanvi siguen normativitzades i quotidianes.

S'ha usat el vocable de «ceguera mental» per a descriure metafòricament el problema cognitiu característic de l'autisme: les dificultats en la comunicació i interacció social junt amb la dificultat de llegir les ments alienes explica aquesta denominació. El moviment neurodiversitat, tal com s'aplica a l'autisme, proposa que l'autisme (en algunes de les seues manifestacions, almenys) és una forma diferent de ser que s'ha de respectar i donar suport. S'argumenta que els autistes pensen de les persones amb desenvolupament típic que són excessivament volubles, desordenades, amb dificultats per a processar i memoritzar, i tenen raó. Probablement, hàgem de reconèixer que entre les persones amb aquesta afecció es troben algunes amb característiques personals i intel.lectuals excel/lents, algunes d'elles per tenir focus d'atenció molt centrats i interessos molt intensos en alguns objectius, són persones molt competents en les exigències escolars i laborals. 


\section{UNA REALITAT: ES MANTÉ I FINS I TOT MILLORA EN L'ANCIANITAT}

Per a finalitzar, s'abordaran les últimes etapes del cicle vital.

No ens sobren els estudis sobre les conseqüències de conèixer la ment dels altres en poblacions d'adults majors. Els estudis són contradictoris. $\mathrm{Hi}$ ha un treball clàssic d'una autora anglesa que va passar tasques de mentides, persuasions, dobles sentits, ironies, etc., i va trobar que participants de més de setanta anys van ser més lents que els i les joves, però van resoldre millor les tasques. Aquesta autora concloïa en el seu treball que la millora podria atribuir-se a l'augment de la versió cognitiva que es coneix com a saviesa. La saviesa, que ha sigut definida com un conjunt d'habilitats integrades d'aspectes afectius, cognitius i comunicatius, és una capacitat humana desitjable que permet resoldre tasques conflictives en què es troben implicats, especialment, els problemes més vitals. No obstant això, fa ja bastant temps que sabem que la saviesa, una vegada sobrepassada l'adolescència, no està relacionada amb l'edat o la intel-ligència, sinó que són aspectes de la personalitat els que es coordinen i asseguren un sentit savi de la realitat: l'obertura a l'experiència, la prosocialitat o la generativitat, entre altres.

Altres treballs que no troben resultats tan positius atribueixen les dificultats de les persones grans al deteriorament executiu o a la generació (cohort) de referència, implicant amb això a les possibilitats educatives que tenen o han tingut les cohorts joves. En els països occidentals, les persones que tenen més de 75/80 anys han tingut poques oportunitats - com a col-lectiu - de rebre educació en nivells secundaris o universitaris si se'ls compara amb cohorts més recents. L'escola (en tots els seus nivells) és un fort motor cognitiu que activa el cervell en proposar contínuament nous problemes per resoldre, siguen aquests vertaders o didàctics. Educació $\mathrm{i}$ edat combinen els seus efectes i mantenen una alta correlació amb els assoliments mentalistes.

Si ens centrem en aspectes de la teoria de la ment afectiva, és a dir, si ens interroguem sobre l'emocionalitat o la comprensió i utilització de les emocions per part dels adults grans, el més habitual és trobar referències que descriuen excel-lents anys per a afavorir pensaments positius que estiguen 
propiciats per la interacció amb persones que demostren ser capaços de fer-nos sentir bé. La gent gran, més que la joventut, expliciten haver gaudit d'experiències positives i no haver tingut (o haver evitat), en moments recents, situacions que generen estrès, enuig, tristesa o frustració; també poden sentir més que les persones joves emocions mesclades, sabent que els successos són polièdrics i que poden percebre's des de diverses òptiques i mirades.

Les persones grans veuen les situacions conflictives o les seues pròpies dificultats amb acomodació, però no amb desesperació, de manera que accepten els successos negatius de forma més natural que els i les joves. Açò no es deu a dificultats mentals (els ancians i ancianes més competents cognitivament són els que millor actuen d'aquesta manera) o a egoisme (és una defensa del propi jo que no vol desaprofitar l'oportunitat de viure). L'explicació més encertada és la que fa una atribució al temps, al temps que s'ha viscut i al temps que s'aspira a viure. Se suposa que a l'ancianitat és molt més conscient que a la joventut del pas del temps i pel què s'esforcen a respondre de forma positiva, d'adaptar-se als problemes sense desesperació ni frustració (quelcom difícil per a la joventut) que per la seua pròpia edat tenen projectes de vida ambiciosos i amb possibilitats obertes, amb un temps ocupat en multitud de tasques pròpies de la vida adulta com ara ocupar-se de la criança, dels requeriments laborals, del suport econòmic, etc.

Els majors viuen més el moment, saben el que és important, les seues prioritats són concretes i directes, les coses poc rellevants deixen de ser importants i sobretot, es busquen interaccions interpersonals gratificants, amistats i companyies de temps Iliure capaços de buscar les bones possibilitats que la vida va proporcionant en cada moment i, així, d'aquesta manera, la sensació de felicitat i qualitat de vida millora.

Cal destacar, per a finalitzar, com al llarg de la nostra vida anem recorrent el trajecte amb altres $\mathrm{i}$-encara que condicionats per la biologia- el nostre cervell va trobant raons per a coparticipar amb els altres en la nostra pròpia trajectòria vital.

Rector Magnificus, lectio inaguralis dicta est. 


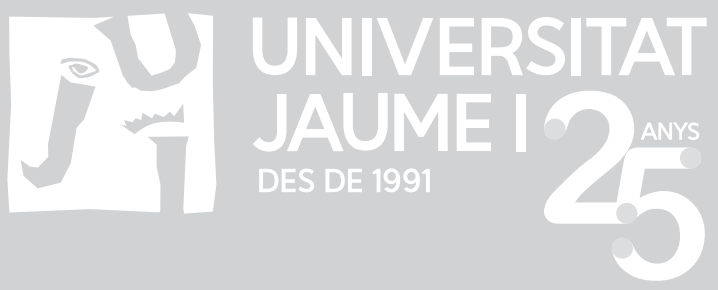

